\title{
Visszajáró svéd kísértet? Egy félreértés fogságában: a svéd modell álma és a kelet-közép-európai realitás
}

\begin{abstract}
A kilencvenes évek eleji súlyos válságot követően a föáramba tartozó makroközgazdászok szinte egyöntetüen temették az ún. „svéd modellt", a müködő piacgazdaság és a bőkezű jóléti állam egykor sokak által csodált és irigyelt kombinációját. A XXI. század elején azonban Svédország és a többi észak-európai állam ismét kiváló értékelést a kap egyrészt a különböző versenyképességi indikátorok, másrészt a humán fejlettség jelzőszámai szerint is. Márpedig az állami újraelosztás mértéke az északi országokban, köztük is Svédországban a legmagasabb a fejlett államok körében. Ráadásul az aktív munkapiaci politikák révén fennmaradt a kiterjedt állami szerepvállalás a munka világában is. Eszerint Svédország ismét komoly intellektuális kihívást jelent a Washingtoni Konszenzusban megfogalmazódó alapvetéseknek? Vagy a svéd gazdaság müködése alapvetően változott meg, és a harmadik utas kísérlet bukása után ma ismét normális piacgazdaság, néhány sajátos, az észak-európai országokra általában jellemző vonással? Az alábbi írásban e két lehetséges értelmezés mögött felsorakoztatható föbb makrogazdasági érveket mutatjuk be.
\end{abstract}

\section{Bevezetés}

A Világgazdasági Fórum „Globális Versenyképességi Jelentés 2005-2006” című évkönyve szerint az Egyesült Államok mellett, a délkelet-ázsiai kistigriseket is megelözve, az észak-európai országok (Finnország, Svédország, Dánia, Norvégia és Izland) a világ legversenyképesebb gazdaságai. Ugyancsak irigylésre méltó képet fest ezekről az államokról az ENSZ humán fejlettséget mérö indexe, amely szerint az észak-európaiak ezen a téren is tipikusan jobban teljesítenek, mint az angolszász, a rajnai vagy az ázsiai kapitalizmus centrumországai. Az újkeletü empirikus evidenciák fényében mintha újjáéledni látszana az egyszer - a kilencvenes évek második felében - már lezárulni látszó vita: lehet-e reális alternatívája a fóáramba tartozó angolszász piacgazdasági rendszereknek a kiterjedt jóléti állam, amely „makacsul nem akar sem összezsugorodni, sem /.../ 'el-

Bartha Attila a Debreceni Egyetem Közgazdaságtudományi Kar Doktori iskolájának levelező doktorandusz hallgatója, a Kopint Datorg Rt. munkatársa. E-mail:a.bartha@kopint.hu Bartha Attila a Kopint-Datorg tudományos fö́munkatársa, Ph.D. hallgató a Debreceni Egyetem Közgazdaságtudományi Karán. E-mail:a.bartha@kopdat.hu 
halni’” (Szamuely 2004:949). Lehetséges, hogy korán temették (Pollock 1998) a modern harmadik út archetípusát, a svéd modellt? Mégse lenne helytálló Lindbeck feltevése, mely szerint „a 'svéd modell' /.../ egy rövid történelmi epizódnak fog bizonyulni, egy olyan közjátéknak, mely a hatvanas évek közepétől a kilencvenes évek elejéig tartott, azaz nem több mint három évtizedig" (Lindbeck 1998(9):69)? Valóban létezik Észak-Európa különössége, valamiféle rejtély (puzzle), melyre joggal csodálkozik rá többek között Krugman (1999) is? Vagy éppen ellenkezőleg: a mai svéd - és a többi észak-európai - gazdaság éppen azért sikeres, mert a svéd kísérlet fö vonásai ma már a történelemkönyvekben szerepelnek csupán (Rojas 2005), és Svédország nem csak a sokrétűen gondoskodó jóléti állam kiépítésében, hanem annak reformjában, netán felszámolásában is úttörőnek bizonyult (Lindbeck 1998)?

E kérdésekre adott válaszok ideológiailag lényegesen terheltebbek a szokásosnál, miközben gyakran messzemenő következményük van gazdaságpolitikai döntésekre is. A kelet-közép-európai országokban mindenesetre tipikusan pozitív az észak-európai (mindenekelőtt a metaforává nemesedő svéd $\left.{ }^{1}\right)$ kísérlet recepciója, amely sokak számára még ma is a harmadik út ígéretét hordozza. Az alábbi írás elsősorban arra keresi a választ, hogy a jelenben megfigyelhetö gazdasági sikerek mennyiben tudhatók be a svéd (északi) modell meghatározó elemeinek, vagy éppen ellenkezőleg: a jelenlegi sikerek inkább a kilencvenes évek elejéig folyó kísérlet felfüggesztésének és a reformoknak köszönhetők. Nem tekintem át valamennyi említett északi ország fejlődési pályáját, hanem Svédországra, a modell - avagy a mítosz és a kísérlet - archetípusára koncentrálok. A történeti fejlemények leírásánál Lindbeck (1998) már idézett írását követem, ezt azonban a legutóbbi időkig elérhető statisztikai adatok elemzésével és az újabb irodalmakban fellelhető tanulságok bemutatásával egészítem ki. Végig törekszem a komparatív perspektíva fenntartására, különösen a kelet-közép-európai országok, így köztük Magyarország számára releváns tapasztalatok kifejtésére.

\section{Makrogazdasági helyzetkép}

Ami a gazdasági fejlettség szintjét illeti, nemzetközi összevetésben egyértelmű, hogy az eltelt egy évtizedben Svédországnak sikerült visszafordítania a relatív pozícióvesztéssel járó tendenciát. Miközben 1970-ben (Luxemburgot leszámítva) Svédország vitathatatlanul Európa leggazdagabb országa volt, addig a kilencvenes évek első felére - Lindbeckkel szólva a kísérlet kifulladásának idejére - az egy före jutó nemzeti jövedelem már a nyugat-európai átlag szintje alá süllyedt. Azóta viszont Svédországban az évi átlagos növekedés 2,8\% volt, ami nemcsak az EU-15 átlagát haladja meg 0,3 százalékponttal, de az egy före jutó GDP-t tekintve az Egyesült Államokhoz képest is relatív pozíciójavulás következett be, az eltérő ütemü - Svédországban az amerikainál lényegesen lassabb - népességnövekedés miatt (Konjunkturinstitutet 2005).

\footnotetext{
1 Kiválóan érzékelteti ezt „a svéd társadalom, amely ma a jóléti állam megtestesült utópiája” szófordulat Enquisttől (1998). De még az összeomlás drámáját ábrázoló irodalmi müvek is elöszeretettel fordulnak - igaz, ez esetben leleplező éllel - a svéd mítoszhoz: „Az őt körülvevő Svédország most omlott össze, mint egy óriási polcrendszer.” (Keresztesi József: A nap vége. Könyvkritika Henning Mankell: Hamis nyomon c. könyvéröl /Budapest, 2005,/, Élet és Irodalom, 2005. szeptember 23., 49. évf. 38. sz.).
} 
Az egy före jutó GDP aktuális vásárlóerő-paritáson (EU-15=100)

\begin{tabular}{|l|c|c|c|c|}
\hline & $\mathbf{1 9 7 0}$ & $\mathbf{1 9 9 0}$ & $\mathbf{1 9 9 5}$ & $\mathbf{2 0 0 4}$ \\
\hline Dánia & 115 & 106 & 114 & 112 \\
\hline Finnország & 93 & 104 & 91 & 104 \\
\hline Svédország & $\mathbf{1 2 4}$ & $\mathbf{1 0 9}$ & $\mathbf{9 7}$ & $\mathbf{1 0 8}$ \\
\hline Eurózóna & 98 & 99 & 100 & 98 \\
\hline EU-15 & 100 & 100 & 100 & 100 \\
\hline
\end{tabular}

Forrás: (Lindbeck 1998) és Eurostat-adatok alapján saját számítás

Fontos, hogy ez a 2,5-3\% közötti ütemü (vagyis az átlagos nyugat-európai trendértéknél lényegesen gyorsabb) növekedés rövid és középtávon is fenntarthatónak tünik. Szerkezetileg kedvező, hogy erőteljesen nő a bruttó állóeszköz-felhalmozás - ezen belül is a gépi beruházások - súlya a GDP-ben (5-6\% közötti növekedés), miközben a folyó fizetési mérleg az ezredforduló óta évről évre a GDP 5-8\%-ára rúgó többlettel (!) zár, köszönhetően mindenekelött a dinamikusan - az importét messze meghaladó ütemben - bővülő exportnak. A leglátványosabb fordulat - ami ezt a fenntarthatóságot döntő mértékben megtámasztja - persze a fiskális politikában figyelhető meg. Miközben a kilencvenes évek elején hihetetlen mértékü - 1993-ban, a válság mélypontján a GDP arányában közel 12\%-os - államháztartási hiányt regisztráltak, 1998 óta a svéd államháztartás rendre többlettel zár (ez alól szerény kivételt jelentett 2002, a nemzetközi konjunkturális trendforduló éve, amikor az államháztartás hiánya a GDP 0,3\%-a volt). Ennek köszönhetően a bruttó államadósság trendje is határozottan csökkenő: az ezredfordulót megelőző két évtizedben a GDP 60\%-át elérő adósságráta 2004 végére 51,1\%-ra mérséklődött, és a Svéd Pénzügyminisztérium előrejelzése szerint 2010-re GDP-arányosan $40 \%$ alatti szintre süllyed (Regeringskansliet 2005).

A makrogazdaság más dimenzióiban is a stabilitás, az egyensúlyi helyzet a jellemző. Nyilvánvaló az árstabilitás: az utolsó 12 hónapban az éves átlagos infláció Svédországban mindössze 0,8\% volt, Finnország után a második legalacsonyabb az Európai Unióban. Ez a tendencia valamennyi mértékadó előrejelzés (Konjunkturinstitutet 2005; Regeringskansliet, 2005; European Commision 2005) a következő években is fennmarad, aminek köszönhetően a magas svéd árszínvonal relatíve közelebb kerül a többi európai ország árszintjéhez. Bár a svéd korona 1992 novembere óta szabadon lebeg, az euróhoz viszonyított árfolyama meglehetősen stabil, leértékelés semmi esetre sem fenyegeti, inkább enyhe felértékelődési nyomás tapasztalható az utóbbi években. Ezzel egyidejüleg a hosszú távú (10 éves) német államkötvényekhez viszonyított kamatfelár - amely a kilencvenes évek közepén még több mint 4 százalékpont (!) volt - 2000 óta eltünt, sőt 2005 második felére negatívba fordult.

A stabilitás melletti fokozatos javulást mutatnak a jövedelmi és a munkapiaci indikátorok is. Mivel évről évre mérsékelt (1-2,5\% közötti) a munkajövedelmek emelkedése, ami ráadásul kiugró termelékenységnövekedéssel párosul, a termékegységre jutó reálbérköltségek trendje határozottan csökkenő. Mindez ugyanakkor némi hullámzással 
párosul a munkapiacon: a foglalkoztatottak száma az elmúlt öt évben stagnált, a munkanélküliek aránya viszont $5 \%$ környékéröl $6 \%$ feletti szintre emelkedett. A fiatalok és a bevándorlók elhelyezkedési nehézségei nyilvánvalóak; ezzel együtt 2004-ben a foglalkoztatási arány - a 15-64 éves korcsoport 72,1\%-a - Dánia és Hollandia után a harmadik legmagasabb volt az Európai Unióban, mégpedig úgy, hogy a nők, illetve a férfiak foglalkoztatási rátája egyaránt meghaladta a $70 \%$-ot. Ráadásul valamennyi mértékadó elörejelzés (pl. Regeringskansliet 2005, European Commission 2005) a következő évekre egyszerre számol jelentős foglalkoztatásbővüléssel és a munkanélküliség csökkenésével.

Összességében ez a helyzetkép kifejezetten kedvező, és lényegében valamennyi dimenzióban pontosan ellentétes azzal, ami a kísérlet kifulladásának idején, a kilencvenes évek első felében jellemezte Svédországot (gazdasági visszaesés, magas államháztartási hiány, növekvő államadósság, instabil árfolyam, megugró infláció, drámaian emelkedő munkanélküliség). A pillanatnyi makrogazdasági helyzetkép tehát egyértelmüen pozitív, és a kilencvenes évek első felét jellemző válsághoz képest túlzás nélkül drámai a változás. A kérdés ettől persze még kérdés marad: e változás a svéd modellen belül ment végbe (vagyis a modell inherens önkorrekciós képességének tudható be), vagy éppen ellenkezőleg, a változás pontosan annak köszönhető, hogy a kísérlet feladásra került. A továbbiakban erre a kérdésre keressük a választ.

\section{Az új északi modell a klasszikus svéd modell tükrében}

Talán nem véletlen, hogy a Svédországot újra felfedező szerzők közül egyre többen (pl. Aiginger 2004; illetve Fischer - Matthiessen 2005) nem pusztán svéd modellről, annak újjászületéséről, hanem inkább valamiféle északi modellről értekeznek, hiszen Dánia, illetve Finnország gazdasági-társadalmi sikerei hasonlóképpen látványosak. A kedvező eredmények mögött hasonló makroökonómiai, gazdaság- és társadalompolitikai jellemzők húzódnak meg. A következőkben Fischer és Matthiessen (2005) nyomán ennek az új északi modellnek a jellemzőit mutatjuk be.

Az első jellemző az aktív állami szerepvállalás, amely a jóléti kérdésekre és ezen belül a társadalombiztosítás területére széleskörüen kiterjed, megőrizve a jövedelmi és a vagyoni egyenlőtlenségek mérséklésének célját. A második jellemző a közkiadások magas arányára vonatkozik, magas adókkal és a közszférában foglalkoztatottak ugyancsak magas hányadával. A harmadik jellemző az aktív munkapiaci politikák fennmaradása, amely mindenekelőtt a magas foglalkoztatásra és munkapiaci részvételre irányul. A negyedik jellemző a központi béralkuk jelentős (bár csökkenő) szerepe, amely a társadalmi partnerek erőteljes befolyásával párosul. Az ötödik jellemző a szabadkereskedelmi irányzat egyértelmű előnyben részesítése a protekcionista megoldásokkal szemben. Végül a hatodik: az innováció kérdésének kiemelt kezelése. Ha ezeket a jellemzőket összehasonlítjuk a Lindbeck (1998) által leírt svéd kísérlet elemeivel, bizony számos hasonlóságot tapasztalhatunk. Ilyenek a széleskörü jóléti állami célkitüzések, az aktív munkapiaci politika és a központi béralkuk szerepe, de ide tartozik a szabadkereskedelmi irányzat preferenciája is.

Az elvi folytonosság tehát legalább részben fennmaradt, ugyanakkor a svéd kísérlet számos eleme nem része az új modellnek: a kormányzatok nem törekszenek az aggregált megtakarítások, a hitelkínálat és a beruházások szoros szabályozására, illet- 
ve allokációjuk befolyásolására; visszaszorult a helyi önkormányzatok szoros központi kormányzati felügyelete; nem szükségképpen jellemző a magángazdaság oligopolisztikus nagyvállalati koncentrációja sem.

A két „modell” (vagyis a két időszak) között végbemenő változások első látásra értelmezhetők úgy, mintha döntően a svéd modellre jellemző ideológiai túlhajtások szorultak volna csak vissza, miközben a modell alapjellemzői változatlanok maradtak. Megítélésem szerint azonban ennél alapvetően többről van szó. A GDP-arányos államháztartási kiadások Svédországban 15 százalékpontot meghaladó (de Dániában és Finnországban is jelentős) csökkenése nem pusztán mennyiségi, hanem gazdaságpolitikai-gazdaságideológiai változást is jelez: a fiskális fenntarthatóság, vagyis a hosszútávon fenntartható államháztartási hiány gondolata a gazdaságpolitikai döntéshozatal megkerülhetetlen paramétere lett. Szemben a Magyarországon - és néhány más keletközép-európai országban - széles körben elterjedt vélekedésekkel, az univerzális (szociáldemokrata-institucionális) jóléti állam eszméjét ma már ideológiailag szervesen kiegészíti, praktikusan - a gazdaságpolitikai döntések során - pedig valójában megelőzi a hosszú távú fiskális fenntarthatóság elve.

2. táblázat

Az államháztartás jellemzői az északi országokban (a GDP \%-ában)

\begin{tabular}{|l|c|c|c|c|}
\hline \multirow{2}{*}{} & $\mathbf{1 9 9 3}^{*}$ & $\mathbf{2 0 0 4}$ & $\mathbf{1 9 9 3}^{*}$ & $\mathbf{2 0 0 4}$ \\
\cline { 2 - 5 } & \multicolumn{1}{|c|}{ Államháztartási egyenleg } & \multicolumn{2}{|c|}{ Államháztartási kiadások } \\
\hline Dánia & $-3,7$ & 2,8 & 61,7 & 55,6 \\
\hline Finnország & $-7,2$ & 2,1 & 64,2 & 50,7 \\
\hline Svédország & $-\mathbf{1 1 , 4}$ & $\mathbf{1 , 4}$ & $\mathbf{7 3 , 0}$ & $\mathbf{5 7 , 4}$ \\
\hline Eurózóna & $-5,7$ & $-2,7$ & 53,5 & 48,6 \\
\hline
\end{tabular}

*Megjegyzés: a krízis mélypontja

Forrás: (Fischer - Matthiessen 2005)

Nemcsak erről van azonban szó. A másik legfontosabb változás összefoglalóan abban ragadható meg, hogy a paternalista állam esélyteremtő állammá alakul át (Rojas 2005). Egyrészt tehát megmaradnak a jóléti állami célok, amelyek azonban mindig szigorúan kontrolláltak a fenntarthatósági szempontok által. Másrészt a piaci elemek, a választás szabadsága, illetve az öngondoskodás olyan klasszikusnak számító jóléti állami területeken is megjelennek, mint az oktatás, az egészségügy, illetve a nyugdíjbiztosítás.

Az oktatás területén a kilencvenes évek első felében bevezetett - szabad intézményválasztással - kombinált jogosultsági rendszer egyértelműen teljesítményösztönzőnek bizonyult, és egyre több önkormányzat alkalmazza a gyermekgondozás, a nyugdíjellátás, illetve a betegápolás területén is.

Szembeötlő, hogy a nyugat-európai országok között Svédország a nyugdíjreform területén, a hagyományos felosztó-kirovó rendszer reformjában az élenjárók közé tartozott. Nem lehet eléggé hangsúlyozni a kilencvenes évek eleji mély válság termékeny, 
ideológiai purgatóriumként is funkcionáló hatását. Az egyenlősítő felfogás helyébe a rendkívüli, nagymértékủ kockázatok elleni védelem elve (Semjén 1999) lépett. Ebben a megközelítésben a szociális ellátásoknak nem kell védelmet nyújtania a hétköznapi, kismértékü likviditási problémákkal szemben. A transzferrendszer fenntartása azokra az esetekre indokolt, amikor az ellátások a kivételes költségek kockázatát közömbösítik. A nyugdíjrendszer esetében például ez azt jelenti, hogy az állami újraelosztás csak ott lép közbe, ahol az egyéni befizetések utáni nyugdíj nem biztosítja a minimális megélhetést, egyébként - alapesetben - mindenki maga gondoskodik befizetéseivel saját nyugdíjáról.

Összehasonlító perspektívából fontos kitérni arra, hogy Svédország, illetve általában az északi államok miért voltak inkább képesek a jóléti állam számos vívmányának megőrzése mellett a hosszú távú fenntarthatóság irányába történő elmozdulásra - és e célból fundamentális reformok végrehajtására -, mint a rajnai kapitalizmus országai. Gedeon (2001) szerint a jóléti állam és a politikai demokrácia közötti összefüggések miatt a lehetséges szociálpolitikai reformok jobban érinthették az állami szolgáltatásokat, mint a pénzügyi transzferekhez kötődő társadalombiztosítási jogosultságokat. Ennek függvényében nem meglepő, hogy „az állami szolgáltatásokat középpontba helyező svéd jóléti állam radikálisabb változásokon esett át, mint a pénzügyi transzferekre összpontosító német állam" (Gedeon 2001:144).

Valamennyi fent áttekintett tanulmány egyetért abban, hogy Svédországban a jóléti reformok következtében ugyan csökkent a szolgáltatások formális egyenlösége (pontosabban uniformizáltsága), ugyanakkor szükség esetén a szolgáltatások szélesebb körét a társadalom nagyobb hányada tudja igénybe venni, mint korábban. Ha a „svéd modell” reformjának kérdését leszűkítve, pusztán a jóléti rendszer egyik (szociáldemokrata-institucionális) válfaja archetípusának reformjaként értelmeznénk, úgy a kiadáscsökkentés, az egyes alrendszerek önfinanszírozó jellegének erősítése és az ellenösztönző hatások visszaszorítása lenne e reform fö pénzügyi jellemvonása. Miközben a szolgáltatásintenzív jelleg változatlan maradt, a verseny fokozására, a túlzott felhasználás csökkentésére és a pazarlás megszüntetésére irányuló reformok az egészségügy (és az oktatás) területén is egyértelmű piaci irányú elmozdulást mutattak. Korábbi önmagához képest tehát, a svéd jóléti rendszer a liberális modell felé mozdult el, fontos azonban észrevenni, hogy a magánszolgáltatók szerepének erősödése döntően a közösségi finanszírozás keretein belül történik. A szolgáltatások fokozatos differenciálódása alapvetően a jóléti állammal szemben megváltozott igényekhez történő alkalmazkodást jelenti, ennélfogva Semjén (1999) megfogalmazása szerint nem a jóléti állam felszámolásáról, hanem a kor igényeihez való igazításról van szó.

Mindez a jóléti politika hangsúlyainak áthelyeződését is jelenti: az új északi modellben a munkaerő képzése és mobilitásának növelése kerül a középpontba. Rojas (2005) szerint ugyanakkor a demográfiai változások, a függőségi arány kedvezőtlen irányú módosulása (az eltartó/eltartott arány csökkenése), valamint, egyfelől az elöregedő társadalom növekvő bevándorlási szükséglete, másfelől a korábbi bevándorlók integrációjának figyelmeztető kudarcai belátható időn belül olyan problémákat jelentenek, amelyek kezelésére a jelentős változásokon átesett svéd jóléti rendszer sem képes. Tegyük hozzá: e probléma legalábbis pán-európai, hiszen az elöregedő Európai Unió egész területére (de a majdan csatlakozó új tagországokra is) jellemző. 


\section{Szerkezeti változások az államháztartási kiadások területén}

A fenti szkeptikus vélemények ellenére Svédország korábban már idézett legfrissebb, 2005. novemberi konvergenciaprogramja (Regeringskansliet 2005) az elkövetkező években nem számol az államháztartás finanszírozásának számottevő módosulásával. Tervek szerint 2005-2008 között az adóztatás GDP-arányos mértéke alig egy százalékponttal (49,5\%-ra) csökken, és az állam összes bevételei a GDP 54,7\%-ára rúgnak majd. Valamivel nagyobb (közel 1,4 százalékpontos) csökkenés várható az államháztartási kiadásoknál - változatlan kamatfizetési kötelezettség mellett -, amelyek 2008-ban a GDP $53,1 \%$-át érhetik el. Vagyis várhatóan középtávon is fennmarad a GDP mintegy 1,5\%-át elérő államháztartási többlet, amely 2008-ig összességében a bruttó államadósság közel 5 százalékpontos csökkenését vetíti előre (a GDP 46\%-ára).

A svéd kísérlet és reformja szempontjából persze nem elégedhetünk meg a kiadások aggregált tárgyalásával: a közkiadások minőségét - vagyis az államháztartási kiadások területeinek változását - szintén át kell tekinteni. 1995-2003 között az összes államháztartási kiadás GDP-arányosan 9 százalékponttal csökkent, amelynek legnagyobb része a kamatkiadások 4,3 százalékpontos csökkenése volt. Számottevően mérséklődtek még a társadalombiztosítással, a lakáspolitikával, a közvetlen gazdasági szerepvállalással, a szabadidős tevékenységekkel és a védelemmel kapcsolatos kiadások, miközben érzékelhetően nőtt az oktatás, az egészségügy és a környezetvédelem területére fordított összeg. Bár a legkevésbé sem kívánok egyenlőségjelet tenni egy adott területre fordított közkiadás nagysága, illetve annak változása, és az adott területen mutatkozó ellátás minősége közé - ez a konkrét területek belső hatékonyságának kérdése -, mindenképp szembeötlő, hogy Svédországban az államháztartási gazdálkodás fegyelmezetté válása nem jelentette a munkára fordított kiadások csökkenését. Nemhogy abszolút, de még relatív értelemben - GDP-arányosan - sem.

Figyelemre méltó, hogy a kiadások szerkezetének változásában éppen a Rojas (2005) által számon kért jövőbeli kihívások kezelésének szándéka a meghatározó: „, A jelenlegi gazdasági helyzet lehetővé teszi az előretekintő reformok megvalósítását a munkanélküliség csökkentése és a munkakínálat magas szintjének fenntartása érdekében. Ugyancsak teret enged a kutatás-fejlesztés, a környezetvédelem és az oktatás területei kiemelt kezelésének is" (Regeringskansliet 2005:22).

\section{Munkapiaci folyamatok}

Amint arra fentebb már többször is rámutattunk, számos lényeges változás mellett a klasszikus svéd kísérlet és a megreformált északi modell között mindenképp folytonosságot jelent az aktív munkapiaci politika kiemelkedő szerepe. A kilencvenes évek elején, vagyis a válság időszakában évről évre a munkaképes korú lakosság közel 5\%-a vett részt a különböző kormányzati munkaprogramokban - miközben az ebben résztvevőket számításba nem vevő ún. nyílt munkanélküliségi ráta $8 \%$ körül mozgott (Lindbeck 1998). Bár 2004-re a nyílt munkanélküliségi arány 5,9\%-ra esett vissza, a munkanélküliek számához mérten továbbra is igen sokan vettek részt a kormányzati munkapiaci programokban (a munkaképes korú lakosság 2,4\%-a). A jelek szerint a svéd kísérletnek 


\section{Államháztartási kiadások Svédországban 1995-2003 között (a GDP \%-ában)}

\begin{tabular}{|l|c|c|c|}
\hline & $\mathbf{1 9 9 5}$ & $\mathbf{2 0 0 3}$ & $\begin{array}{c}\text { Változás } \\
\text { (\%-pont) }\end{array}$ \\
\hline Kamatkiadások & 6,6 & 2,4 & $-4,3$ \\
\hline Egyéb általános kiadások & 5,3 & 5,9 & $+0,5$ \\
\hline Védelem & 2,5 & 2,1 & $-0,5$ \\
\hline Igazságszolgáltatás & 1,5 & 1,4 & $-0,0$ \\
\hline Közvetlen gazdasági szerepvállalás & 6,1 & 5,0 & $-1,1$ \\
\hline Környezetvédelem & 0,2 & 0,3 & $+0,1$ \\
\hline Lakás & 2,9 & 0,9 & $-2,0$ \\
\hline Egészségügy & 6,4 & 7,3 & $+0,9$ \\
\hline Szabadidő, kultúra, vallás & 1,9 & 1,1 & $-0,8$ \\
\hline Oktatás & 7,1 & 7,4 & $+0,3$ \\
\hline Társadalombiztosítás & 27,2 & 24,9 & $-2,3$ \\
\hline Összes államháztartási kiadás & $\mathbf{6 7 , 7}$ & $\mathbf{5 8 , 7}$ & $\mathbf{- 9 , 0}$ \\
\hline
\end{tabular}

*Kerekités miatt nem feltétlenül egyezik meg az előző két oszlop különbségével Forrás: (Regeringskansliet 2005)

ez az eleme tehát túlélte a kilencvenes évek elejének mély válságát, és továbbra is kiemelt szerepet játszik a gazdaságpolitikában.

Ugyanakkor a kilencvenes évek folyamán - amint arra Aiginger (2004) rámutat - alapvető változások is zajlottak a svéd munkapiaci politikában. A részmunkaidős foglalkoztatás szigorú szabályozását jelentősen enyhítették, és az OECD által használt általános szabályozási index is számottevően - az 1990-es 3,4-ről 2,4-re - csökkent, amely érték azt jelenti, hogy a kilencvenes évek végén már Svédországban volt a negyedik legrugalmasabb az általános munkapiaci szabályozás az Európai Unió 25 tagállama között (megjegyzendő, hogy Finnországban és különösen Dániában még rugalmasabb volt a szabályozás).

A munka világának ez a változása túlzás nélkül drámai ahhoz képest, amit a svéd kísérletnek az erőszakos szakszervezeti túlhatalommal jellemezhetö időszakában figyelhettünk meg. Modern piacgazdaságokban szinte elképzelhetetlen, ami Svédországban 1983. október 4-én megtörtént: tulajdonosi és menedzsmentjogaik védelmében a töketulajdonosok országszerte tömegtüntetésekre kényszerültek (Henrekson - Jakobsson 2001). A megelőző időszakban a szakszervezetek felrúgták a munkaadók és a munkavállalók közötti kooperatív viszonyulás hagyományát, amelynek gyökerei az 1938-as Saltsjöbadeni Egyezményig nyúltak vissza (Lindbeck 1998). Az adókból finanszírozott ún. „munkavállalói alapok” ötlete, illetve ennek bukása lényegében a svéd piaci szocia- 
lizmus kísérletének ideológiai bukását is jelentette (bár a makroökonómiai összeomlás csak néhány évvel később lett nyilvánvaló).

A kooperatív magatartás - az ideológiai túlhajtások miatt kirobbanó konfliktusok rendeződése után normális mederbe visszaálló - svéd hagyománya és a munkavállalók erős érdekérvényesítése szempontjából a globalizáció és az Európai Unión belüli szabad munkaáramlás persze új kihívást jelent. A közelmúlt híres esete volt ezzel kapcsolatban az ún. Vaxholm-ügy, amelyben az alacsonyabb fizetésü lett munkásokat alkalmazó cég munkáját sikerrel lehetetlenítette el a svéd Építőipari Szakszervezetek Szövetsége (Carlén 2005). Megjegyzendő, hogy a munkavállalók mellett a munkaadók képviselői is a svéd modell inherens részének tekintik a harmincas évek vége óta müködő kooperációt, amelynek két eleme a központi béralku és az erőszakos munkabeszüntetéstől való tartózkodás (Lundqvist 2005).

Mégis azt kell mondanunk, hogy a hetveneses évekre jellemző helyzethez képest - amikor Svédország valóban közel került egyfajta szocializmushoz (Henrekson - Jakobsson 2001) - mára a munka világában is visszaállni látszik az a felek kooperatív magatartására épülő rend, amely kompatibilis a piacgazdasággal. A hetvenes évek végén már a svéd közvélemény zömét vállalkozás- és vállalkozó-, illetve menedzserellenes attitűdök jellemezték, amely a „munkavállalói alapok” bevezetése ötletének - a tulajdonosok nélküli szocialista vállalatok létrehozásának - ideológiai támaszt is adott. Végül nem szilárdult meg azonban a „laborizmus”, amelyet Schumpeter 1942-es, a szocializmus, a kapitalizmus és a demokrácia összefüggéseiről írott munkájában a kapitalizmus azon - a szocializmust közvetlenül megelöző - utolsó szakaszának tekintett, amelyben a „munka érdekei az uralkodók” (idézi: Henrekson - Jakobsson, 2001:334). Az átmenetileg erősödő antikapitalista attitüdök mellett is egyre nyilvánvalóbbak lettek azok a hatékonysági problémák, amelyek végül is nem a Tinbergen (1968) által jövendölt kapitalizmus és államszocializmus közötti konvergencia bekövetkeztéhez, hanem a két rendszer közötti divergenciához vezettek. A tulajdonosi jogok radikális korlátozásának kísérlete Svédországban elbukott, a munkavállalói szervezetek túlhatalma átmenetinek bizonyult. Az új északi modell Svédországa a piacra, a gazdasági szereplők racionális cselekvésére és az innovációra épülő kapitalista gazdaság, amelyben ugyanakkor az újraelosztásnak és az állami aktív munkapiaci politikának ma is lényegesen nagyobb a szerepe, mint a fejlett világ más országaiban.

\section{Összegző megjegyzések}

Az alábbi írásban a svéd modell reneszánsza mögött meghúzódó okokat kíséreltem meg feltárni. Alapvetően arra a kérdésre kerestem a választ, hogy létezik-e valamiféle svéd (északi) különösség, rejtély (puzzle), amely ellentmond a standard közgazdasági bölcsességnek. Vajon a svéd kísérlet mégsem bukott el a kilencvenes évek elején, hanem releváns, netán a piacgazdaság és a jóléti állam összeegyeztethetősége folytán vonzó és reális alternatívát kínál a kelet-közép-európai országoknak? Feltettem a kérdést, hogy Svédország eszerint jelent-e ismét valódi kihívást a Washingtoni Konszenzusban megfogalmazódó alapvetéseknek (Brook 2004).

A kilencvenes évek közepéhez képest Svédország relatív pozíciója jelentősen javult az Európai Unión belül, és az éves átlagban 2,5-3\% közötti növekedés hosszabb távon is fenntarthatónak tünik. E növekedés kedvező szerkezetben, erőteljes beruházási akti- 
vitás és a folyó fizetési mérleg számottevő többlete mellett megy végbe. Szemben a kilencvenes évek elejére jellemző állapottal, az utóbbi években Svédország rendre jelentős államháztartási többlettel zár, aminek következtében érzékelhetően csökken az államadósság. A makrogazdasági helyzetkép jelenleg egyértelműen pozitív, ez azonban a korábbi kísérlet kiigazításának (és nem folytatásának) köszönhető.

Bár fennmaradt az aktív állami szerepvállalás, annak hatóköre jelentősen módosult. A paternalista állam esélyteremtő állammá alakult. A fiskális fenntarthatóság szempontjai ma elsődlegesek az egyenlősítő ideológiával és a jóléti állami terjeszkedéssel szemben. Sőt, az egyenlősítő felfogással szemben az öngondoskodás, illetve a rendkívüli, nagymértékủ kockázatok elleni védelem elve a meghatározó. A nyugdíjrendszer, az oktatás és az egészségügy területén is a kvázi-piaci, versenyt erősítő és szolgáltatáskínálatot bővítő reformlépések történtek.

A svéd államháztartás kiadási szerkezete jelentősen módosult: lényegesen csökkent az állam közvetlen gazdasági szerepvállalása a lakással, szabadidővel és a védelemmel kapcsolatos kiadások terén, miközben az oktatással, egészségüggyel és környezetvédelemmel összefüggő területekre abszolút értékben és a GDP arányában is többet fordítanak, mint korábban. Az új északi modellben az innovációs, illetve kutatási-fejlesztési kiadások kiemelt szerepet kapnak.

Bár megmaradt az aktív munkapiaci politika kiemelt szerepe, a hetvenes évekre jellemző antikapitalista attitüdökkel párosuló szakszervezeti dominancia időszaka ma már ritkán érhető tetten, és immár nem része a modell (módosult) genetikai programjának. Svédország a kísérlet végén visszatáncolt, és mégsem lett szocialista gazdaság.

A harmadik út, legalábbis a svéd kísérlet értelmében, nem járható a kelet-középeurópai országok számára. A fiskális fenntarthatóság szempontjainak betartásával természetesen nagyon is indokolt lehet bizonyos - az északi modellben kulcsszerepet játszó - területek kiemelt kezelése, miként az öngondoskodás és a verseny elemeinek erősítése a korábbi jóléti rendszer által átfogóan felölelt területek szinte mindegyikén is. A régi svéd kísérlet tehát nem jelent reális alternatívát a felzárkózó új EU-tagállamoknak. Nincs különösebb talány, legfeljebb kísértés vagy kísértet. 


\section{Hivatkozások}

Aiginger, Karl (2004): Copying the US or developing a New European Model - policy strategies of successful European countries in the nineties. UN-ECE Spring Seminar, Genf.

Brook, Daniel (2004): How Sweden Tweaked the Washington Consensus. Dissent Magazine, ősz. www. dissentmagazine.org

Carlén, Stefan (2005): Protecting the Nordic model. In: Building a social Europe: the trade union case for EU reform. Kézirat.

Enquist, Per Olov (1998): Stockholm. Lettre, 29. sz.

European Commission (2005): Sweden. Economic Forecasts, ősz. http://europa.eu.int

Fischer, Jonas - Matthiessen, Jens (2005): How bright are the Nordic lights? ECFIN Country Focus, 2. évf 14. sz. http://europa.eu.int

Gedeon Péter (2001): Merre tart a német jóléti állam? Társadalombiztositási alrendszerek Németországban. Közgazdasági Szemle, 48. évf. 2. sz. 130-149.

Henrekson, Magnus - Jakobsson, Ulf (2001): Where Schumpeter was nearly Right - the Swedish Model and Capitalism, Socialism and Democracy. Journal of Evolutionary Economics, 11. sz. 331-358.

Krugman, Paul (1999): Who knew? The Sweden Model is working. The Unofficial Paul Krugman Web Page. www.pkarchive.org

Lindbeck, Assar (1998 [1997]): A svéd kísérlet I-II. rész. Külgazdaság, 42. évf. 7-8. sz. 57-89. és 9. sz. 56-74.

Lundqvist, Torbjörn (2005): The Employers in the Swedish Model. Institute for Futures Studies. Arbetsrapport, 2.sz.

Konjunkturinstitutet (2005): The Swedish Economy. Augusztus. www.konj.se

Pollock, Robert L. (1998): A Socialist 'Third Way' Turns Out to Be a Dead End. National Center for Policy Analysis. www.ncpa.org

Regeringskansliet (2005): Update of Sweden's convergence programme. November. http://europa. eu.int

Rojas, Mauricio (2005): Sweden after the Swedish Model. From Tutorial State to Enabling State. Timbro, Stockholm.

Szamuely László (1992): A jóléti állam - válság és stabilitás. In: Változó struktúra, változó ipari társadalom. Kopint-Datorg, Budapest, 209-287.

Szamuely László (2004): A „haldoklo" jóléti állam az 1990-es években. Közgazdasági Szemle, 51. évf. 10. sz. 948-969.

Semjén András (1999): A svéd jóléti rendszer átalakulása. Közgazdasági Szemle, 46. évf. 4.sz. 326345.

Tinbergen, Jan (1968): Development Planning. Weidenfield \& Nicholson, London.

United Nations Development Programme (2005): Human Development Report.

World Economic Forum (2005): The Global Competitiveness Report, 2005-2006. 